TE DEUM: Jurnal Teologi dan Pengembangan Pelayanan

Volume 10, Nomor 2 (Juni 2021): 181-203

ISSN 2252-3871 (print), 2746-7619 (online)

http://ojs.sttsappi.ac.id/index.php/tedeum/index

DOI: https://doi.org/10.51828/td.v10i2.39

\begin{tabular}{|l|l|l|}
\hline Submitted: 23-2-2021 & Accepted: 3-6-2021 & Published: 25-6-2021
\end{tabular}

\title{
IBADAH ONLINE DALAM PERSPEKTIF ALKITAB DAN RELEVANSINYA PADA MASA SERTA PASCA PANDEMI COVID 19
}

\author{
Sunarto \\ Sekolah Tinggi Teologi SAPPI, Ciranjang \\ snartaa@gmail.com
}

\begin{abstract}
The main problem in writing this article is can the church hold services online? At first there were those who disagreed, but there were also those who agreed. So the purpose of writing this article is to describe the biblical basis that is the reference for holding worship online. Explain the advantages and disadvantages of offline worship. Explain the advantages and disadvantages of worship online. Explain the relevance of online worship during and after the Covid-19 pandemic. Besides describing these matters, this article is also an effort to enlighten the true nature of Christian worship in entering a new era in a pandemic era and the rapid development of digital technology. The research method in writing this article is literature analysis with descriptive methods. The conclusion is that online worship during and after the Covid-19 pandemic is still relevant to be held.
\end{abstract}

Key Phrases: online worship, pandemic, Covid-19

\section{ABSTRAK}

Masalah utama dalam penulisan artikel ini adalah bolehkah gereja menyelenggarakan ibadah secara online? Pada awalnya ada yang tidak setuju, tetapi juga ada yang setuju. Jadi tujuan dari penulisan artikel ini ingin menguraikan dasar Alkitab yang menjadi acuan bagi penyelenggara ibadah secara online. Menjelaskan keunggulan dan kelemahan dari ibadah secara offline. Menjelaskan keunggulan dan kelemahan dari ibadah secara online. Menjelaskan relevansinya ibadah online pada masa dan pasca pandemi Covid-19. Di samping menguraikan hal-hal tersebut artikel ini sekaligus sebagai upaya pencerahan terhadap hakikat ibadah Kristen yang benar 
dalam memasuki era baru di masa pandemi dan perkembangan yang pesat dalam teknologi digital. Metode penelitian dalam penulisan artikel ini adalah analisis kepustakaan dengan metode deskriptif. Kesimpulannya adalah ibadah online di masa dan paska pandemi Covid-19 masih tetap relevan untuk tetap diselenggarakan.

Frasa Kunci: ibadah online, pandemi, Covid-19.

\section{PENDAHULUAN}

Salah satu topik pembicaraan ketika munculnya virus corona (SARSCoV-2) atau lebih dikenal Covid-19 adalah tentang ibadah online. Fakta ini dapat dilihat dari berbagai media seperti Youtube atau Facebook yang banyak digunakan oleh berbagai gereja dalam menyelenggarakan ibadah secara online. Kasus kematian pertama oleh virus corona pertama kali dilaporkan oleh pemerintah Cina pada 11 Januari 2020. Sejak saat itu virus ini terus menyebar ke berbagai negara di dunia dan akhirnya menjadi pandemi global yang mengancam setiap orang. ${ }^{1}$ Di Indonesia pun pada akhirnya tidak bisa membendung serangan virus ini. Akhirnya pada 2 Maret 2020, untuk pertama kalinya pemerintah Indonesia mengumumkan dua kasus pasien positif Covid-19 di Indonesia. Namun, pakar Epidemiologi Universitas Indonesia (UI) Pandu Riono menyebutkan virus corona jenis SARS-CoV-2 sebagai penyebab Covid-19 itu diperkirakan sudah masuk ke Indonesia sejak awal Januari. ${ }^{2}$

Sejak saat itu dunia digegerkan dengan berita-berita virus corona atau lebih dikenal Covid-19. Topik virus corona akhirnya menjadi salah satu topik yang selalu menjadi pokok perbincangan di kalangan orang banyak, termasuk orang Kristen atau kehidupan dalam gereja. Hampir setiap hari media cetak atau media online seperti Kompas.com selalu memberitakan perkembangan terbaru tentang covid-19, termasuk berbagai media televisi sering memberitakan topik ini.

Sebelum masa pandemi Covid-19 (di Indonesia Maret 2020) pada dasarnya ibadah online sudah dilakukan oleh sebagian gereja atau persekutuan-persekutuan Kristen, tetapi ibadah online tidak menjadi pilihan banyak gereja seperti sekarang ini. Pandemi virus corona yang menyebar ke seluruh dunia membuat gereja mengalami kebingungan karena berdasarkan

${ }^{1}$ John Piper, Coronavirus and Christ (Kristus Dan Virus Corona) (Surabaya: Literatur Perkantas, 2020), 6 .

2Ellyvon Pranita, "Diumumkan Awal Maret, Ahli: Virus Corona Masuk Indonesia Dari Januari," Kompas.Com, 2020, https://www.kompas.com/sains/read/2020/05/11 /130600623/diumumkan-awal-maret-ahli--virus-corona-masuk-indonesia-dari-januari. 
pada ahli kesehatan mereka menyetujui bahwa berkembangnya virus ini oleh karena terjadinya penularan antar manusia. Virus menjadi menyebar kemana-mana karena adanya orang-orang sakit yang menularkan orang sehat.

Berbagai kalangan menyerukan bahwa untuk menanggulangi berkembangnya virus corona setiap orang harus menjauhi berbagai pertemuan yang melibatkan banyak orang. Gereja sebagai salah satu tempat perkumpulan banyak orang dihimbau, bahkan sempat dilarang untuk sementara untuk digunakan sebagai tempat beribadah pada hari Minggu atau dalam kegiatan apapun. Karena masyarakat dilarang berkumpul pada satu tempat atau harus menghindari berbagai bentuk kerumunan. Akibatnya semua kegiatan ibadah di gereja ditiadakan, Sebagian gereja memutuskan untuk menyelenggarakan ibadah secara online, sebagian bahkan meliburkan anggota jemaat sehingga jadwal ibadah menjadi terhenti atau dampaknya gedung gereja menjadi kosong. Situasi demikian menunjukkan bahwa sebagian gereja menjadi gagap ketika mereka tidak bisa menggunakan teknologi untuk bisa menyelenggarakan ibadah secara online.

Berdasarkan penelitian lapangan yang dilakukan oleh Langfan tentang ibadah online dapat digambarkan bahwa kebaktian online tidak terlalu memberikan dampak yang baik khususnya dalam hal rasa hormat dan takut atau kesungguh-sungguhan jemaat kepada Tuhan melalui ibadah. Ibadah yang dilaksanakan melalui online, khususnya dalam hal rasa hormat dan takut atau kesungguh-sungguhan jemaat tidak sama dengan waktu beribadah di gereja. Ibadah di gereja memang memiliki unsur rasa hormat dan takut atau kesungguh-sungguhan jemaat kepada Tuhan namun dalam ibadah online tidak demikian. Penelitian ini termasuk dalam lingkup yang terbatas karena hanya melibatkan 25 responden atau tanggapan, ${ }^{3}$ dengan demikian belum bisa menggambarkan secara luas bagaimana sikap tersebut apa juga dialami di tempat (gereja) yang lain.

Salah satu penelitian literatur yang sudah membahas tentang isu ibadah secara online dilakukan oleh Tambunan. Penelitian Tambunan diarahkan untuk menggali landasan dasar konsep teologis adanya ibadah online di pascapandemi covid-19. Hasil penelitiannya menyatakan bahwa teknologi sebagai anugerah dari Allah diberikan kepada manusia untuk

3Onisimus Langfan, "Ibadah Online Di Masa Pandemi Covid-19: Implementasi Ibrani 12:28," Stella: Jurnal Teologi Dan Pendidikan Kristen 1, no. 1 (2021): 15-18, http://sttse.ac.id/e-journal/index.php/stella. 
digunakan dan Allah bisa memakai dalam pekerjaan-Nya, termasuk dalam ibadah secara online di masa Covid-19. Ibadah secara online di pascapandemi covid-19 tidak bertentangan dengan firman Allah yang paling penting adalah kehadiran Allah dan persekutuan orang percaya. ${ }^{4}$ Sekalipun sudah membahas landasan teologis ibadah secara online, tetapi penelitian tersebut belum banyak membahas secara khusus apa kelemahan dan keunggulan dari ibadah online dan offline.

Berbeda dengan hal tersebut penelitian ini disamping menguraikan landasan dasar Alkitab bagi pelaksanaan ibadah secara online, juga secara khusus menguraikan apa kelebihan dan keunggulan dari ibadah secara online dan offline. Jadi penulisan artikel ini secara khusus akan membahas bolehkah gereja menyelenggarakan ibadah secara online dan relevansinya pada masa pandemi serta pasca pandemi covid-19. Ada yang setuju, tetapi ada juga yang menolak ibadah online, bahkan ada yang menilai kalau ibadah online bukan ibadah yang sesungguhnya, tetapi racun yang masuk ke dalam kehidupan dalam gereja. Adakah dasar Alkitab yang menjadi acuan bagi penyelenggara ibadah secara online? Adakah dasar Alkitab yang menjadi acuan untuk menolaknya? Apa keunggulan dan kelemahan dari ibadah secara online? Masih relevankah ibadah online ketika masa pandemi covid19 sudah berakhir? Berbagai pertanyaan tersebut memerlukan pendalaman yang kuat sehingga bisa menjadi acuan bagi gereja atau orang Kristen, sekaligus sebagai jawaban untuk mereka yang ragu atau menentang bagi penyelenggara ibadah secara online.

\section{METODE PENELITIAN}

Metode penelitian yang digunakan dalam artikel ini adalah metode deskriptif. Penelitian ini memberikan informasi berupa catatan dan data deskriptif yang terdapat di dalam teks yang diteliti. ${ }^{5}$ Metode deskriptif adalah suatu metode dalam meneliti fakta status sekelompok manusia, suatu objek, suatu kondisi, suatu sistem pemikiran atau pun suatu peristiwa pada masa sekarang dengan menafsirkannya secara tepat. ${ }^{6}$ Sedangkan metode operasional yang digunakan dalam menyelesaikan masalah

"Fernando Tambunan, "Analisis Dasar Teologi Terhadap Pelaksanaan Ibadah Online Pascapandemi Covid-19," EPIGRAPHE: Jurnal Teologi Dan Pelayanan Kristiani 4, no. 2 (November 28, 2020): 154, https://doi.org/10.33991/epigraphe.v4i2.210.

5Sedarmayanti and Syarifudin Hidayat, Metode Penelitian (Bandung: Mandar Maju, 2011), 33 .

${ }^{6}$ Ensiklopedi Alkitab Masa Kini, Jilid I (Jakarta: Yayasan Komunikasi Bina Kasih, 1997), 409. 
menggunakan metode analisis, yaitu menyelidiki, memeriksa dan memerinci semua masalah dalam setiap aktivitas pekerjaan, menginterprestasikan masalah tersebut dan memberikan sebuah kesimpulan. Ada pun sumber data yang digunakan adalah buku-buku kepustakaan, jurnal yang terkait dengan topik-topik yang relevan dan sumber-sumber penting lainnya yang bisa dipertanggungjawabkan.

\section{HASIL DAN PEMBAHASAN \\ PENGERTIAN IBADAH KRISTEN}

Sebelum membahas pengertian ibadah secara offline dan online, ada baiknya harus dipahami dulu apa itu pengertian ibadah secara umum bagi orang Kristen. Kosa kata ibadah atau ibadat dalam Alkitab sangat luas, tetapi konsep asasinya baik itu dari dalam Perjanjian Lama atau Perjanjian Baru adalah "pelayanan". Kata Ibrani ibadah berasal אבד (avoda) dan Yunani latreia yang pada mulanya menyatakan pekerjaan budak atau upahan. Sedangkan kata Ibrani hisytakhawa atau kata Yunani proskuneo dalam rangka mempersembahkan ibadah kepada Allah, para hamba-Nya harus meniarap, hal ini menyatakan bahwa ibadah harus diungkapkan dengan rasa takut penuh hormat, kekaguman dan ketakjuban penuh puja. ${ }^{7}$

Tekanan utama dalam ibadah Perjanjian Lama bukan hanya dilakukan sebagai jemaat atau satu komunitas sebagai umat, tetapi ibadah juga dilakukan secara pribadi-pribadi (Kej. 24:26; Kel. 33:9-34:8). Ibadah secara perorangan juga menempati peran penting dalam kehidupan umat Tuhan. Seperti apa yang dikatakan oleh David Peterson "Alkitab menyatakan melalui berbagai cara bahwa hubungan dengan Allah yang sejati didasarkan kehidupan doa dan puji-pujian pribadi."8

Namun ibadah sebagai umat atau jemaat sangat ditekankan dalam Perjanjian Lama (Maz. 42:4; 1 Taw 29:20). Perjanjian Lama juga mengatur bagaimana ibadah itu dikerjakan, terkait dengan tempat dan waktu. Dalam Kemah pertemuan ketika Israel masih dalam perjalanan di padang gurun masalah ibadah juga diatur, demikian juga ketika di Bait Suci sudah dibangun yaitu zaman Salomo, format ibadah sudah diatur sedemikian rupa. Ibadah harian dan perayaan khusus, misalnya perayaan Paskah dan

7David Paterson, Liturgika: Sebuah Teologi Penyembahan (Malang: Gandum Mas, 2017), 10.

${ }^{8}$ Ensiklopedi Alkitab Masa Kini, Jilid I, 409. 
hari Pendamaian menempati hal penting dalam kalender ibadah tahunan orang Yahudi atau bangsa Israel. ${ }^{9}$

Ketika bangsa Israel dibuang ke negeri Babel, kehidupan dalam ibadah tidak ditinggalkan oleh mereka. Karena mereka hidup di negeri pembuangan tentunya tidak bisa lagi beribadah di Bait Suci di Yerusalem. Inilah yang melatar belakangi bahwa ibadah pada perkembangannya tidak lagi berpusat pada satu tempat utama atau gedung seperti Bait Suci. Inilah yang menjadi cikal bakal orang-orang Yahudi mulai beribadah di Sinagoge. Tampaknya ibadah ini bermula pada abad ke-6 sM ketika orang-orang Yahudi berada dalam pembuangan di Babel. ${ }^{10}$

Dalam Perjanjian Baru pada awalnya para murid-murid Kristus juga masih beribadah di Bait Suci (Kis. 2:46; 3:1 ) dan Sinagoge yang juga digunakan sebagai ibadah orang-orang Yahudi pada umumnya (Kis. 13:14; 14:1). Para murid atau orang-orang percaya disamping menggunakan Bait Suci dan Sinagoge sebagai tempat beribadah mereka juga menggunakan rumah secara bergantian sebagai tempat untuk beribadah secara bergantian (Kis. 2:46b). Jadi ibadah Kristen adalah suatu ungkapan untuk menyatakan rasa takut, hormat, puji syukur dan pujian serta sukacita kepada Tuhan karena telah mengasihi dan yang menyelamatkan sehingga melalui ibadah itu orang percaya bisa berjumpa dengan Allah dan mengenal apa yang menjadi kehendak-Nya.

\section{PENGERTIAN IBADAH OFFLINE}

Istilah offline adalah suatu istilah untuk sebutan saat seseorang tidak terhubung dengan internet, lebih tepatnya tidak terkoneksi. ${ }^{11}$ Apabila kata tersebut dikaitkan dengan pengertian ibadah secara offline berarti suatu kegiatan ibadah yang dilakukan oleh seseorang, beberapa orang atau banyak orang tanpa menggunakan jaringan internet sebagai salah satu sarana dalam beribadah.

Pengertian ibadah secara offline adalah persekutuan yang diselenggarakan orang-orang percaya atau orang-orang Kristen yang berkumpul di satu gedung gereja atau satu ruang pertemuan tertentu untuk berdoa, memuji Tuhan, membaca firman Allah dan mendengarkan

${ }^{9}$ Ensiklopedi Alkitab Masa Kini, Jilid I, 409.

${ }^{10}$ James F. Whife, Pengantar Ibadah Kristen (Jakarta: BPK Gunung Mulia, 2017), 140.

11"Pengertian Online Dan Offline Secara Lebih Jelas (," n.d., http:/ /www.pengertianku.net/2015/01/pengertian-online-dan-offline-secara-lebihjelas.html). 
khotbah, memberikan persembahan dan atau melakukan sakramen yang diimani oleh setiap orang percaya. Menyelenggarakan ibadah secara offline harus dihadiri oleh jemaat secara langsung karena ibadah ini hanya diselenggarakan di satu tempat atau gedung dan tidak ditayangkan melalui berbagai media sosial seperti: live streaming, siaran langsung Facebook, Instagram, Zoom meeting dan media sosial lainnya.

Istilah lain dari ibadah secara offline atau on site karena dalam ibadah ini menuntut adanya pertemuan secara langsung antara para pelayan ibadah: pendeta, majelis jemaat atau penatua, pemimpin pujian atau liturgos dengan anggota jemaat yang ingin mengikuti ibadah. Jadi antara pelayan ibadah dengan umat ada pertemuan secara langsung pada jam tertentu dan di tempat tertentu. Apabila umat berhalangan untuk hadir dalam ibadah di satu gereja maka seseorang tidak bisa mengikuti ibadah ini karena pada umumnya penyelenggaraan ibadah ini tidak menggunakan jaringan internet.

\section{PENGERTIAN IBADAH ONLINE}

Istilah online adalah saat seseorang sedang terhubung dengan internet atau dunia maya, baik itu terhubung dengan akun media sosial, email dan berbagai jenis akun lainnya dengan menggunakan jaringan internet. ${ }^{12}$ Apabila kata tersebut dikaitkan dengan pengertian ibadah secara online berarti suatu kegiatan ibadah yang dilakukan oleh seseorang, beberapa orang atau banyak orang menggunakan jaringan internet sebagai sarana dalam beribadah. Ibadah secara online bisa diikuti oleh seseorang atau beberapa orang, bahkan banyak orang yang tidak terikat oleh satu tempat tertentu atau gedung selagi di tempat tersebut terjangkau dengan jaringan internet.

Apabila dalam ibadah offline antara pelayan ibadah dengan jemaat menuntut pertemuan secara langsung dan dalam waktu yang sudah ditentukan di suatu tempat. Sebaliknya dalam ibadah online tidak menuntut satu pertemuan secara langsung antara pelayan ibadah dengan jemaat, karena ibadah ini dapat diikuti dimana pun tempatnya. Bahkan ibadah online bisa diikuti oleh seseorang ketika sedang dalam perjalanan selama di daerah itu terjangkau dengan jaringan internet.

Ada berbagai sarana atau aplikasi digital yang bisa digunakan dalam ibadah online seperti: Youtube secara live streaming, rekaman Youtube (prerecord streaming), Facebook, Zoom meeting, Google Meet dan berbagai media sosial lainnya. Ibadah yang disiarkan melalui media Youtube live

12"Pengertian Online Dan Offline Secara Lebih Jelas (." 
streaming artinya dilakukan dengan konsep kerja seperti siaran langsung pada televisi. Artinya, pemilik konten melakukan kegiatan perekaman pada suatu konten dan secara langsung disiarkan pada media yang dimilikinya. ${ }^{13}$ Sedangkan rekaman Youtube (prerecord streaming) dijalankan dengan terlebih dahulu merekam video atau konten yang akan disiarkan, kemudian menyimpannya pada media tertentu (bisa media online atau media fisik seperti hardisk). Setelah disimpan, baru kemudian host dapat melakukan akses pada konten tersebut jika akses diberikan secara bebas oleh pemilik konten. ${ }^{14}$

Jadi ibadah secara online artinya suatu kegiatan beribadah yang diikuti oleh seseorang, beberapa orang atau banyak orang dengan menggunakan jaringan internet sebagai salah satu sarana dalam beribadah.

\section{Dasar-Dasar Alkitab IBADah ONLINE}

\section{Esensi Ibadah Itu Bukan Masalah Gedung}

Ibadah adalah persekutuan orang-orang percaya untuk membaca firman, bersaksi, berdoa, memuji Tuhan, memberikan persembahan kepada Tuhan dan atau melakukan perjamuan Tuhan (Kis. 2:1-4; 41-47). Pada zaman Alkitab orang-orang percaya beribadah di Bait Suci (Kis. 3:1), di Sinagoge atau rumah ibadat (Kis. 13:14-15) juga dilakukan di rumah-rumah (Kis. 2:46). Apa yang mereka laksanakan jelas melakukan ibadah bukan karena gedung atau tempatnya, tetapi karena mereka sedang memuji Tuhan, memberitakan firman Tuhan atau Injil Kristus dan berdoa kepada Allah. Demikian juga pada masa pandemi covid-19 ketika gereja mengambil keputusan ibadah secara online, apa yang dilaksanakan oleh orang-orang percaya pada masa kini adalah beribadah. Mereka disebut beribadah bukan karena aplikasi digitalnya, tetapi esensinya adalah sama, yaitu persekutuan orang-orang percaya yang sedang berdoa, memuji Tuhan dan memberitakan Injil Kristus.

Sangat jelas substansi ibadah orang-orang percaya pada dasarnya bukan terletak pada tempat atau gedung yang digunakan dalam beribadah. Substansi ibadah bukan karena menggunakan jaringan internet, live streaming, Facebook, Instagram dan lainnya sebagainya. Substansi ibadah orang-orang percaya terletak pada makna persekutuan itu sendiri, yaitu membaca dan mempelajari firman Tuhan seperti yang tertulis dalam Alkitab, bersaksi dan memberitakan Injil Kerajaan Sorga, berdoa dan

13"Pengertian Streaming Serta Jenis dan Penerapannya," BAKTI Info.id, 2019.

14"Pengertian Streaming Serta Jenis dan Penerapannya." 
memuji Tuhan, serta merayakan karya Kristus melalui meja perjamuan Kudus.

Gedung atau waktu yang digunakan orang-orang percaya untuk beribadah bisa berbeda-beda, tetapi persekutuan yang dilakukan setiap orang percaya adalah mengimani Allah yang sama, yang sudah menyelamatkan orang berdosa melalui karya salib Kristus. Ibadah online pada masa pandemi Covid-19 yang memaksa orang-orang percaya untuk menghindari pertemuan dalam jumlah yang besar atau banyak orang mengingatkan pada masa-masa awal berdirinya gereja orang-orang percaya juga beribadah di rumah sebagai tempat mereka beribadah.

Mereka yang berkumpul sekalipun dipisahkan oleh rumah atau tempat yang berbeda mereka adalah orang-orang percaya yang telah mendengarkan Injil dan menerima Kristus sebagai Tuhan dan juru selamat. Ibadah secara online menjangkau dan menyatukan semua orang percaya untuk bersekutu dan bersaksi kepada dunia karena dalam ibadah online bisa diakses oleh semua orang sekalipun sebelumnya seseorang belum mendengarkan berita Injil. Jadi mereka yang menolak ibadah secara online dengan menilai kalau ibadah ini bukan ibadah yang sesungguhnya jelas tidak memahami hakikat tentang ibadah itu sendiri. Ibadah itu persekutuan orang-orang percaya yang melintasi semua batasan gedung atau tempat seseorang.

\section{Kuasa Firman Tidak Dibatasi Waktu dan Tempat}

Setiap firman yang diberitakan oleh para pemberita firman atau pengkhotbah baik yang dihadiri oleh sedikit atau banyak orang hakikatnya memberitakan apa yang menjadi mandat dari Allah sendiri. Seperti yang dikatakan oleh Allah melalui nabi Yesaya bahwa kuasa firman-Nya tidak akan kembali secara sia-sia, artinya kalau Allah berkehendak melalui firmanNya pasti akan terlaksana, kuasa-Nya tidak bisa dibatasi oleh waktu atau tempat di mana pun manusia berada. Demikian dikatakan oleh Allah melalui Yesaya: "demikianlah firman-Ku yang keluar dari mulut-Ku: ia tidak akan kembali kepada-Ku dengan sia-sia, tetapi ia akan melaksanakan apa yang Kukehendaki, dan akan berhasil dalam apa yang Kusuruhkan kepadanya (Yes. 55:11).

firman itu pula yang terus diberitakan oleh murid-murid Kristus atau orang-orang percaya dari satu gedung atau tempat ke tempat yang lain. Para penulis keempat Injil semua menuliskan firman tujuannya supaya dapat dibaca dan diberitakan oleh para pengikut Kristus (Mat. 28:19-20; Mrk 16:15,20; Luk. 1:1-4; Yoh. 21:24-25). Demikian rasul-rasul menuliskan 
firman tujuannya utamanya adalah memberitakan firman supaya dapat dibaca oleh jemaat Tuhan pada permulaan. Petrus dipakai oleh Allah untuk menuliskan firman-Nya, Paulus menuliskan banyak kitab atau surat tujuannya supaya setiap orang percaya atau jemaat Tuhan bisa hidup yang dilandasi oleh berita firman. Firman itu juga yang terus diberitakan baik secara tertulis atau secara verbal ke berbagai penjuru dunia.

Dalam konteks masa kini ketika gereja menghadapi masa pandemi Covid-19 yang mengharuskan jemaat menjaga jarak secara fisik sehingga tidak mungkin hadir di gereja sehingga harus mengikuti ibadah secara online secara esensi firman-Nya tetap diberitakan oleh para hamba-Nya. Dalam ibadah online secara substansial pada dasarnya sama setiap pemberita firman memberitakan firman Allah seperti yang diperintahkan oleh Allah, juga yang diperintahkan oleh Kristus sendiri. Pemberitaan firman dalam ibadah merupakan tanda penting apakah sebuah persekutuan itu dapat disebut sebagai gereja. Tanpa pemberitaan firman sebuah gereja akan diragukan kegerejaan karena Allah memakai firman-Nya untuk mengubah kehidupan ini. Seperti yang dikatakan oleh Dever: "Allah telah memilih untuk memakai firman-Nya untuk membawa kehidupan. Itulah pola yang kita di dalam Alkitab dan di dalam sejarah. firman-Nya adalah alat yang dipilihNya sendiri untuk membawa kehidupan."15

Disebut beribadah bukan karena gedungnya ada dimana, tetapi apakah dalam ibadah itu memberitakan firman Allah. Dalam ibadah online berita firman itu dapat menembus berbagai batasan tempat, sekalipun di daerah tersebut tidak ada gedung gereja. Dalam ibadah online sekalipun antara pengkhotbah dengan para pendengar tidak ada pertemuan secara langsung secara fisik, tetapi firman yang diberitakan itu bisa dipakai oleh Allah untuk mengubahkan orang yang berdosa.

\section{Ibadah adalah Penyembahan dalam Roh dan Kebenaran dengan Melintasi Semua Batasan}

Ibadah itu bukan bicara tentang tempat atau gedung, apakah di Yerusalem atau di Samaria, tetapi penyembahan yang benar kepada kepada Allah. Demikian dikatakan oleh Yesus ketika memberitakan Injil kepada seorang perempuan Samaria, ibadah yang benar harus mengenal pribadi yang disembah, yaitu menyembah Bapa dalam roh dan kebenaran (Yoh. 4:23-24). Terkait dengan roh dan kebenaran disini mengacu pada perlunya

15Mark Dever, Tanda Gereja Yang Sehat (Surabaya: Momentum, 2010), 40. 
ibadah ibadah yang sejati. Allah menghendaki ketika umat-Nya menyembah berada dalam relasi yang baik dengan Bapa. ${ }^{16}$

Secara historis permulaan persekutuan orang-orang percaya pada awalnya belum ada istilah aliran atau denominasi seperti pada zaman sekarang. Perjanjian Baru menggunakan sebutan para murid Kristus yang berkumpul di satu tempat untuk beribadah berdasarkan nama kota atau desa dalam suatu wilayah. Sebutan untuk jemaat berdasarkan nama kota atau tempat misalnya jemaat atau gereja di Yerusalem (Kis 2:1,5; 6:7), jemaat di Yudea (Kis 8:1b), jemaat di Antiokhia (Kis. 11:19), jemaat di Filipi (Kis. 1:1), jemaat di Tesalonika dan lain sebagainya.

Rasul Paulus yang banyak merintis dan mendirikan berbagai gereja di Asia dan di Eropa dalam suratnya sering menekankan bahwa semua murid Kristus pada dasarnya adalah satu jemaat Tuhan. Demikian dikatakan kepada jemaat di Kolose apa pun latar belakang suku atau rasnya, apakah ia orang Yahudi, orang Yunani, orang bersunat atau tidak bersunat, orang Barbar orang Sakit, budak atau orang merdeka, semua orang percaya diselamatkan oleh karya Kristus (Kol. 3:11). Bukan hanya orang-orang percaya yang berkumpul di Kolose, tetapi semua murid Kristus di seluruh dunia.

Ibadah itu melintasi semua batasan aliran atau organisasi gereja karena yang disembah oleh semua orang percaya adalah sama. Semua orang percaya adalah satu tubuh, satu Roh, satu Tuhan, satu iman, satu baptisan, satu Allah dan Bapa dari semua apa pun latar belakang rasnya (Ef. 4:4-6). Mereka adalah orang-orang berdosa yang diselamatkan oleh karya Kristus yang telah mati disalibkan.

Munculnya aliran atau denominasi gereja pada dasarnya dilatarbelakangi oleh adanya pemahaman teologi dan perpecahan dalam gereja. Benih-benih perpecahan dan perbedaan pemahaman tentang iman Kristen bukan hanya terjadi pada abad 16 yang pada akhirnya melahirkan Gereja Katolik Roma dan Gereja Protestan. Pada abad ke 4 pergumulan masalah Kristologi juga menjadi perdebatan yang tajam antara yang dipahami oleh Arius dan Athanasius. Pergumulan ini sekaligus yang melatarbelakangi sehingga gereja harus menggelar persidangan gereja yang pertama, yaitu konsili Nicea (325M). ${ }^{17}$

16Donald Guthrie, Tafsiran Alkitab Abad Ke-21, Jilid 3 Matius - Wabyu (jakarta: Yayasan komunikasi Bina Kasih, 2017), 214.

${ }^{17}$ B.K. Kuiper, The Church in History (Malang: Gandum Mas, 2010), 35-37. 
Maka jelaslah bahwa hakikat ibadah itu bukan bicara masalah tempat, gedung atau organisasinya, tetapi terkait penyembahan yang benar. Ibadah yang benar juga terkait dengan sikap yang benar dihadapan Allah, bukan masalah apakah ibadah itu online atau offline. Jadi dalam konteks ibadah secara online setiap orang percaya yang beribadah harus menyembah Allah dengan rasa hormat dengan memuji Tuhan, berdoa dan mendengarkan firman-Nya. Jaringan internet dan media digital hanya merupakan sarana dalam beribadah, sama seperti ibadah secara offline juga memerlukan sarana sehingga ibadah itu dapat dilaksanakan dengan baik.

\section{KEUNGGULAN DAN KELEMAHAN IBADAH ONLINE}

\section{Keunggulan Ibadah Online}

Pada masa pandemi Covid-19 hampir sebagian besar gereja yang memiliki fasilitas pendukung penyelenggaraan ibadah secara online. Meskipun pada awalnya diwarnai oleh berbagai perdebatan antara yang setuju atau yang menolak adanya ibadah secara online. Kecuali sebagian gereja oleh karena berbagai keterbatasan perlengkapan atau sarana, termasuk tidak dimilikinya sumber daya manusia mereka tidak bisa menyelenggarakan ibadah secara online. Berikut akan diuraikan berbagai keunggulan atau kelebihan dari ibadah yang dilakukan secara online:

\section{Ibadah Online Menembus Batasan Tempat atau Gedung}

Apabila ibadah diselenggarakan secara offline atau on site ibadah itu hanya diselenggarakan pada tempat atau gedung gereja berarti anggota jemaat yang ingin beribadah harus pergi ke gereja tersebut. Hal sebaliknya tidak terjadi pada gereja yang menyelenggarakan ibadah secara online karena ibadah ini bisa diikuti oleh anggota jemaat di rumah masing-masing. Ibadah online bisa diikuti oleh seseorang sekalipun ia sendiri di dalam rumah. Jadi dalam ibadah online bisa diikuti oleh satu orang, beberapa orang dalam satu keluarga, atau bahkan oleh banyak orang yang berkumpul di suatu gedung atau tempat pertemuan.

Dalam kondisi normal ibadah secara online bisa diikuti oleh jemaat dalam lingkup sinode baik secara sinode wilayah atau sinode secara nasional. Satu orang pengkhotbah bisa menjangkau semua wilayah, sekalipun itu dipisahkan oleh tempat atau gedung gereja yang terpisah. Dalam ibadah online masalah tempat atau gedung bukan faktor penentu bagi penyelenggaraan ibadah ini, karena jaringan internet dapat mengatasi berbagai hambatan jarak atau tempat. 
Dunia sebelumnya tidak pernah menghadapi bahwa virus corona memaksa dunia mengalami karantina yang demikian meluas, berbagai kota ditutup, perbatasan antara negara ditutup, bandara ditutup, adanya larangan dalam perjalanan, semua kegiatan olah raga dihentikan. Kota besar yang biasanya tidak pernah mati oleh karena aktivitas penduduk kotanya, dipaksa untuk menjadi sepi dan bagaikan kota mati. Mal-mal atau supermarket menjadi kosong, demikian juga gedung-gedung gereja menjadi kosong dari aktivitas kegiatan ibadah. ${ }^{18}$

Dalam konteks ketika dunia secara global menghadapi masa pandemi Covid-19 dimana setiap orang harus menghindari kerumunan orang banyak, maka ibadah online merupakan satu jawaban terhadap masalah ini. Ibadah online merupakan jawaban dari ancaman tertularnya virus corona karena dalam ibadah online anggota jemaat bisa mengikuti ibadah ini secara pribadi lepas pribadi.

\section{Ibadah Online Menembus Berbagai Batasan Organisasi Gereja}

Apabila ibadah secara offline hanya bisa diikuti oleh jemaat yang hadir di suatu gedung gereja atau ruang pertemuan, tidak demikian dengan ibadah yang diselenggarakan secara online. Ibadah secara online bisa diikuti oleh jemaat secara perorangan. Ibadah secara online bisa diikuti oleh jemaat dalam satu keluarga, bisa diikuti juga oleh banyak orang yang berkumpul di suatu gedung manapun, selama daerah tersebut memiliki jaringan internet.

Apabila dalam ibadah secara offline biasanya hanya diikuti oleh jemaat yang berasal dari anggota gerejanya atau simpatisan tetapnya, tetapi ibadah ini bisa menjangkau semua orang di luar anggota jemaat. Pendeta atau majelis jemaat tidak bisa menghalangi anggota jemaat apabila mereka mengikuti berbagai ibadah secara online yang diadakan oleh gereja lain diluar aliran atau denominasinya.

Teknologi digital yang begitu cepat berkembang secara positif bisa memungkinkan gereja menggunakan sarana ini untuk menggelar berbagai kegiatan gerejawi, termasuk ibadah-ibadah pada hari Minggu. Inilah keunggulan dari ibadah secara online bisa menembus berbagai batasan di luar aliran denominasinya. Jemaat manapun dengan mudahnya bisa mengakses dan mengikuti ibadah-ibadah yang diselenggarakan di luar ibadah dari gerejanya sendiri.

${ }^{18}$ John C. Lennox, Where Is God in A Coronavirus World? (Surabaya: Literatur Perkantas Jatim, 2020), 11-12. 


\section{Ibadah Online Mencegah Terjadinya Penularan dari Berbagai Penyakit}

Ketika dunia global harus menghadapi masa pandemi covid-19 berbagai kalangan menghimbau supaya semua orang menghindari kerumunan orang banyak. Virus corona bisa menyebar dengan cepat apabila ada kerumunan orang banyak karena penyebaran virus ini salah satunya melalui media droplet atau air liur yang keluar dari mulut manusia ketika batuk atau bersin. Salah satu aktivitas kegiatan ritual ibadah di gereja adalah menyanyi dan paduan suara, jadi menyanyi memungkinkan seseorang menjadi media bagi penyebaran virus corona. Seperti yang diteliti oleh para ahli di Inggris yang meneliti apakah menyanyi atau paduan suara memiliki dampak yang besar bagi penyebaran virus ini. Demikian dikatakan sebagai berikut:

"Beberapa waktu yang lalu, para ahli di Inggris percaya jika bernyanyi dapat berkontribusi besar dalam penyebaran Covid-19. Ini menimbulkan peraturan yang ketat terkait paduan suara dan sejenisnya. Dalam penelitian terbaru, peneliti kembali menguji dampak menyanyi dalam penyebaran virus. Mereka melihat bahwa bernyanyi tidak menghasilkan lebih banyak partikel pernapasan daripada berbicara. Dengan catatan, memakai volume suara yang sama." 19

Apabila gereja tetap menyelenggarakan ibadah secara offline atau kehadiran secara langsung di sebuah gedung jelas ini memberikan potensi penularan bagi penyebaran suatu penyakit. Apabila ini tetap dipaksakan berarti gereja bukan berpartisipasi untuk memelihara dan menjaga kehidupan yang ada. Kehidupan bangsa Israel pada era Musa sudah mengatur apabila ada yang sakit, misalnya sakit kusta, mereka tidak diperbolehkan tinggal dalam perkemahan umat, tetapi yang tinggal di luar perkemahan. Mereka harus keluar dari perkemahan atau diasingkan di tempat yang terpisah (Im 13:45-46). Mengapa diasingkan dari perhimpunan umat? Bukan semata-mata dianggap najis atau haram, tetapi dari perspektif kesehatan kehadirannyaa bisa menulari mereka yang sehat.

Dalam konteks pada masa pandemi Covid-19 mereka yang dinyatakan positif covid mereka harus menjalani isolasi yang terpisah dari orang pada umumnya. Jadi prinsip isolasi atau memisahkan orang sakit dengan orang sehat pada dasarnya bukan sesuatu yang baru dalam

19"Pola Penyebaran Virus Corona Dan Berita Populer Kesehatan Lainnya," www.com, 2020, https://www.suara.com. 
kehidupan di era digital ini. Kehidupan bangsa Israel sudah menerapkan tentang prinsip isolasi yang mereka yang sakit.

\section{Ibadah Online Bisa Diakses Dimanapun Seseorang Berada}

Keunggulan atau kelebihan lain dari ibadah online yang sangat nyata adalah ibadah ini bisa diakses atau diikuti dimana pun ia berada. Di dalam kota atau di luar kota, di dalam negeri Indonesia atau saat berada di luar negeri. Bahkan ketika seseorang dalam perjalanan ke luar kota oleh sesuatu hal, seseorang bisa mengikuti ibadah online ketika dalam perjalanan. Misalnya ketika seseorang sedang berada di bandara karena mau bepergian keluar kota, bukankah ibadah online bisa diikuti oleh seseorang. Contoh lainnya ketika seseorang sedang dalam perjalanan naik kereta api anggota jemaat juga masih bisa mengikuti ibadah dalam perjalanan tersebut.

Ketika anggota jemaat tidak bisa mengikuti ibadah pada jam yang sudah ditentukan, masalah yang demikian tidak menjadi sebuah halangan karena ia bisa mengikuti ibadah online pada jam yang berbeda. Ibadah online live streaming yang seharusnya diikuti pada jam 08.00 pagi, anggota jemaat bisa menggantinya dengan ibadah pada jam 20.00 karena seseorang bisa mengikuti ibadah melalui siaran ulang atau rekaman.

Kemudahan ibadah online yang bisa diikuti dimana pun ia berada, hal yang demikian tentunya tidak bisa dijalankan dalam ibadah secara offline. Ibadah offline selalu mensyaratkan pada satu tempat atau gedung tertentu dan pada waktu tertentu pula, sebaliknya persyaratan yang demikian tidak dituntut dalam ibadah secara online.

\section{Kelemahan Ibadah Secara Online}

\section{Tidak Ada Hubungan Secara Langsung Antara Pelayan Ibadah dengan Jemaat}

Apabila ibadah yang diselenggarakan secara offline mensyaratkan pertemuan secara langsung antara pelayan ibadah dengan jemaat, pola yang demikian pasti membantu demi tercapainya sebuah ibadah yang tertib atau disiplin. Semua jemaat yang hadir terikat dengan aturan liturgi dalam ibadah tersebut. Dari sisi waktu, jemaat yang hadir akan dituntut untuk tepat waktu pada saat mau mengikuti ibadah. Dari sisi kesopanan terkait dengan pakaian yang dikenakan pada saat ibadah, semua hadir di ruangan ibadah pasti akan memperhatikan pakaian yang pantas dalam sebuah kebaktian.

Apabila ibadah secara offline mensyaratkan pertemuan secara langsung, tidak demikian dalam ibadah yang diselenggarakan secara online. Karena tidak ada pertemuan secara langsung antara pelayan ibadah dengan 
jemaat yang hadir, disinilah muncul berbagai kelemahan dalam ibadah ini. Maka diperlukan tingkat kematangan atau kedewasaan iman dari semua jemaat dalam mengikuti ibadah.

Godaan yang timbul antara lain, jemaat ada kemungkinan tidak mengikuti ibadah sesuai tatanan liturgi yang sudah diatur dalam ibadah tersebut. Misalnya dalam liturgi sudah diatur kalau jemaat diminta untuk berdiri, belum tentu semua jemaat juga ikut berdiri. Pada saat pemimpin kebaktian mengajak umat untuk berdoa apakah semua peserta ibadah yang dirumah-rumah menunjukkan rasa hormatnya dalam ekspresi berdoa, halhal yang demikian menuntut kedewasaan iman bagi setiap orang percaya.

Ibadah yang benar menuntut keterlibatan dari pelayan dan jemaat. Dalami liturgi ibadah juga mengandung aspek sebuah perayaan atau selebrasi. Liturgi sebagai perayaan gereja dilangsungkan ketika ibadah itu sedang digelar. Jadi sifat liturgi ibadah merupakan respons umat akan karya Allah di dalam sejarah dunia. Respons umat atau respons gereja mengandung nilai kebersamaan. ${ }^{20}$ Jadi ketika ketika jemaat mengikuti ibadah secara online meskipun tidak ada hubungan secara langsung, tetap menuntut respons dari setiap orang yang mengikutinya.

\section{Jemaat Kurang Terkontrol pada Saat Ibadah Sedang Berlangsung}

Ada berbagai media yang bisa digunakan sebagai sarana dalam ibadah secara online, diantaranya adalah siaran langsung atau tidak langsung melalui Youtube. Youtube merupakan situs web internet yang popular dimana penggunanya bisa memuat atau berbagi video dengan berbagai konten secara gratis. Media Youtube merupakan aplikasi digital yang bisa digunakan dalam berbagai keperluan diantaranya adalah siaran olah raga, hiburan, termasuk bisa digunakan untuk siaran ibadah Kristen.

Ketika berbicara tentang kelemahan ibadah online, maka perlu memahami apa itu ibadah Kristen. Ibadah Kristen bukan sedang mempertontonkan sebuah aktivitas olah raga atau siaran hiburan bagi jemaat atau masyarakat. Ibadah adalah sikap sangat menghormati atau berbakti, atau sikap yang dinyatakan dalam tindakan-tindakan khusus. ${ }^{21}$

Ibadah Kristen adalah suatu ungkapan untuk menyatakan rasa takut, hormat, puji syukur dan pujian serta sukacita kepada Tuhan karena telah mengasihi dan yang menyelamatkan sehingga melalui ibadah itu orang 2010), 9 .

${ }^{20}$ Rasid Rachman, Pembimbing Ke Dalam Sejarah Liturgi (jakarta: BPK Gunung Mulia,

21Paterson, Liturgika: Sebuah Teologi Penyembahan, 43. 
percaya bisa berjumpa dengan Allah dan mengenal apa yang menjadi kehendak-Nya. Ada perbedaan antara ibadah Kristen dengan ketika seseorang melihat atau sedang menonton siaran olahraga atau ketika menonton film sinetron. Maka sangat jelaslah ada perbedaan antara ibadah Kristen dengan aktivitas kegiatan lainnya. Youtube dengan konten olahraga bisa dinikmati sebagai aktivitas menonton, tidak demikian di dalam ibadah meskipun diselenggarakan secara online.

Jadi apabila dalam ibadah online jemaat tidak mengikuti semua tatanan liturgi yang sudah diatur dalam ibadah, maka tidak tertutup kemungkinan seseorang bisa terjebak pada satu sikap seperti menonton film sinetron. Ibadah Kristen tidak bisa disamakan seperti menonton siaran olah raga, tanpa tuntutan dari semua penonton. Ibadah itu bukan sedang menonton siaran, tetapi menuntut keterlibatan antara pelayan ibadah dengan semua yang hadir. Ibadah Kristen menuntut sikap hati yang benar dan didemonstrasikan dalam ekspresi tubuh yang benar pula.

\section{Respons dari Pendengar Tidak Bisa Dilihat Secara Langsung}

Ibadah secara online karena tidak ada pertemuan secara langsung antara pelayan ibadah dengan jemaat yang hadir maka respons dari hadirin tidak dapat dilihat secara langsung. Ketika seorang pemberita firman berkhotbah kepada jemaat atau para hadirin respons yang diperlukan dari seorang pemberita adalah ekspresi mereka dalam menanggapi berita firman. Khotbah disampaikan oleh seorang pemberita firman bukan sekedar menghabiskan materi khotbah, tetapi menuntut respons hadirin supaya mengetahui, memahami dan melakukan firman-Nya.

Ada ragam materi berkhotbah ketika itu disampaikan dengan tema yang berbeda-beda: ada yang bersifat perintah, pengajaran, nasehat, peringatan, teguran, penghiburan dan lain sebagainya. Semua materi khotbah tersebut menuntut tanggapan atau respons dari para pendengar. Apabila dalam ibadah tidak ada pertemuaan secara langsung tentunya respons diharapkan dari seorang pengkhotbah tidak dapat terlihat dalam ibadah secara online.

Perlu dipikirkan ibadah online yang sedemikian dekat yang bisa menyapa langsung dengan hadirin dalam suatu ibadah. Perlu dipikirkan ibadah online yang interaktif yang bisa menyentuh secara langsung, misalnya menggunakan media Zoom meeting sehingga jemaat yang hadir bisa terpantau hampir sedekat ketika ibadah diselenggarakan secara on site. 


\section{Ibadah Online Bergantung pada Jaringan Internet dan Teknologi Digital}

Jaringan internet merupakan salah satu prasyarat utama untuk bisa menyelenggarakan ibadah secara online. Internet adalah suatu jaringan komunikasi yang memiliki fungsi untuk menghubungkan antara satu media elektronik (misalnya komputer, laptop atau handphone) dengan media elektronik yang lain dengan cepat dan tepat. Jaringan komunikasi tersebut, akan menyampaikan beberapa informasi yang dikirim melalui transmisi sinyal dengan frekuensi yang telah disesuaikan. ${ }^{22}$

Meskipun jaringan internet di Indonesia arealnya semakin diperluas ke berbagai pelosok di seluruh Indonesia, namun harus diakui belum semua wilayah terjangkau oleh jaringan ini. Hanya anggota jemaat yang memiliki komputer, laptop, handphone atau smartphone yang bisa mengikuti ibadah secara online. Tidak semua anggota jemaat memiliki perangkat handphone yang memadai sehingga hal ini juga menjadi pergumulan tersendiri.

Gereja yang menyelenggarakan ibadah secara online memerlukan perangkat yang cukup dan sumber daya manusia yang terampil untuk bisa mengoperasikan semua peralatan pendukung. Dukungan yang tidak kalah penting bagi terselenggarakannya ibadah secara online adalah aliran listrik yang tidak padam. Tidak menutup kemungkinan ketika ibadah online sedang digelar, listrik menjadi padam atau mati, kondisi yang demikian akan membuat halangan bagi kelancaran suatu ibadah.

\section{RELEVANSI IBADAH ONLINE MASA DAN PASCA PANDEMI COVID-19}

\section{Ibadah Online Menjawab Kebutuhan Jemaat pada Situasi Darurat atau Tidak Normal}

Situasi sekarang dapat disebut sebagai era pandemi. Apakah yang dimaksud dengan pandemi? Pandemi adalah wabah penyakit yang terjadi secara luas di seluruh dunia. Pandemi bukan hanya masalah lokal atau nasional, tetapi merupakan masalah dunia secara global dengan kata lain, penyakit ini sudah menjadi masalah bersama bagi seluruh warga dunia. Covid-19 disebut sebagai pandemi karena penyakit ini sudah menyebar ke seluruh dunia. Tidak hanya itu, flu yang saat ini tampak ringan pun pada

${ }^{22}$ Mohammad Robith Adani, "Pengertian Internet, Sejarah, Perkembangan, Dan Manfaatnya," Sekawan Media, 2020, https://www.sekawanmedia.co.id/pengertian-internet. 
masa silam pernah menjadi penyakit yang masuk dalam kategori pandemi dan menjadi masalah bagi seluruh negara di dunia. ${ }^{23}$

Situasi pandemi Covid-19 mengharuskan setiap orang untuk menghindari berbagai kerumunan karena dianggap sebagai sarana penyebaran penyakit. Apabila dikaitkan dengan aktivitas dalam beribadah maka pada era ini jelas dapat disebut sebagai situasi yang darurat. Situasi daurat dapat disebut juga sebagai situasi yang tidak normal. Maka dalam perspektif ini ibadah secara online sangat relevan untuk bisa menjawab pokok permasalahan ibadah yang harus tetap berjalan tanpa mengorbankan arti kesehatan manusia.

Panggilan beribadah bukan diperintahkan oleh manusia, Allahlah yang memanggil umatNya untuk beribadah. Seperti yang dikatakan dalam kitab Ibrani 12:28 demikian: "Jadi, karena kita menerima Kerajaan yang tidak tergoncangkan, marilah kita mengucap syukur dan beribadah kepada Allah menurut cara yang berkenan kepada-Nya dengan hormat dan takut." Penekanan ayat ini jelas memberikan arti bahwa ibadah yang benar bukan tempatnya, tetapi sikap yang benar dihadapan Allah. Di seluruh bagian Kitab Suci, perintah beribadah sangat jelas diperintahkan oleh Allah dan perintah ini menempatkan segala sesuatu dalam ibadah dan juga dalam hidup umatNya harus pada kerangka yang benar (Ul. 6:4-5). ${ }^{24}$

Dalam memenuhi perintah Allah dalam beribadah apabila itu dikaitkan situasi pandemi atau situasi darurat maka ibadah secara online secara substansial tidak mengurangi rasa hormat dan bakti umat untuk datang beribadah. Bagaimana kalau situasi pandemi covid-19 sudah lewat, masih relevankah ibadah ini untuk tetap diselenggarakan? Ibadah secara online masih tetap relevan untuk menjawab pribadi-pribadi tertentu oleh karena kedaulatannya seseorang tidak bisa mengikuti ibadah secara offline, misalnya oleh karena kondisi kurang sehat atau berbagai alasan tertentu.

\section{Ibadah Online Menjawab Kebutuhan Jemaat yang Sedang Lemah Secara Fisik}

Ketika situasi dunia sudah menjadi normal atau masa pandemi sudah lewat, bukan berarti ibadah online tidak diperlukan. Ibadah secara online masih tetap relevan karena tidak semua anggota jemaat selalu bisa hadir di gedung gereja. Mereka yang berusia tua atau lanjut usia atau mereka yang

23"Memahami Epidemiologi Dan Istilah-Istilahnya," n.d., https://www.alodokter. $\mathrm{com} /$ memahami-epidemiologi-dan-istilah-istilahnya.

${ }^{24}$ Mark Labberton, Babaya Ibadah Sejati (Surabaya: Lieratur Perkantas Jawa Timur, 2011), 146-47. 
lemah secara fisik, misalnya sedang sakit, mereka masih bisa mengikuti ibadah secara online.

Lemah secara fisik karena sesuatu penyakit jelas tidak memungkinkan mereka untuk hadir ibadah di gereja. Apalagi kalau kelemahan fisik itu dikarenakan sebuah penyakit yang bisa menular justru mereka dilarang untuk hadir di gereja, sebab kedatangannya bisa menularkan kepada yang lain. Mereka yang sedang lemah secara fisik, tetapi secara rohani mereka tetap sehat juga memiliki kerinduan untuk bisa beribadah. Ibadah online hadir untuk menyapa dan menjawab kebutuhan mereka sehingga bisa tetap beribadah.

Gereja sudah seharusnya menjangkau semua anggota jemaat, termasuk mereka yang kesulitan untuk hadir secara langsung di gereja oleh karena sakit penyakit atau lemah secara fisik. Gereja bisa menyelenggarakan ibadah secara on site maupun secara online, keduanya bisa berjalan secara paralel untuk menjangkau semua anggota jemaat dengan segala situasinya.

Firman Tuhan bukan hanya diberitakan kepada mereka yang sedang dalam kesehatan yang baik, tetapi anggota jemaat yang sedang sakit atau lemah secara fisik juga memerlukan makanan rohani yang bisa menguatkan iman mereka. Justru dalam kondisi lemah mereka membutuhkan kekuatan, dukungan dan penghiburan dari Allah. Bukankah dalam pelayanan Yesus juga memperhatikan mereka-mereka yang sedang sakit atau mereka yang sedang mengalami berbagai ragam kelemahan (Mrk 1:29-34). Dalam kontek ibadah secara online, menjangkau mereka yang lemah tentunya tidak harus hadir secara fisik, tetapi melalui teknologi digital seorang hamba Tuhan bisa hadir untuk menyapa mereka melalui berita firman.

\section{Ibadah Online Menjawab Kebutuhan Pendengar yang Sedang dalam Perjalanan}

Mengingat ibadah secara online dapat menembus semua tempat atau gedung gereja, sepanjang wilayah tersebut terdapat jaringan internet, maka ibadah secara online sangat relevan bagi anggota jemaat yang sedang dalam perjalanan. Ibadah secara substansi bukan terletak pada gedung atau organisasinya, tetapi doa, pujian-pujian dan berita firman yang diberitakan oleh seorang pengkhotbah itu mampu menembus setiap batasan fisik atau materi yang ada di dunia ini.

Bukankah Alkitab mengatakan seperti yang dikatakan Paulus ketika memberikan nasehat kepada hamba Tuhan yang masih muda, yaitu Timotius demikian: "Beritakanlah firman, siap sedialah baik atau tidak baik waktunya, nyatakanlah apa yang salah, tegorlah dan nasihatilah dengan 
segala kesabaran dan pengajaran" (2 Tim 4:2). Kata baik atau tidak baik waktunya berarti perintah untuk memberitakan firman harus dikerjakan dalam kondisi apapun yang ada di dunia ini. Apakah dunia sedang mengalami masa pandemi covid-19 atau tidak, memberitakan firman adalah sebuah keharusan.

Ibadah secara online hadir dengan membuka diri secara aktif untuk menjangkau mereka oleh karena sesuatu hal sehingga tidak bisa mengikuti ibadah di gedung gereja. Melalui ibadah online panggilan gereja sebagai tempat untuk bersekutu, melayani dan bersaksi menjadi lebih maksimal dalam melayani umat serta menjangkau dunia yang gelap ini. Sekalipun demikian ketika kondisi menjadi baik dan memungkinkan untuk hadir, umat harus dipandu untuk mengikuti ibadah secara komunal bersama dengan anggota jemaat yang lain.

\section{KESIMPULAN}

Berdasarkan penelitian tersebut ibadah online pada masa pandemi covid-19 dapat disimpulkan tidak bertentangan dengan Alkitab. Meskipun memiliki kelemahan tetapi itu merupakan hal yang efektif ketika situasi dunia dalam keadaan darurat atau tidak normal. Hakikat ibadah Kristen yang diselenggarakan secara offline atau online secara substansial pada dasarnya adalah sama. Ibadah Kristen itu bukan gedungnya, tetapi persekutuan orang-orang percaya. Ibadah adalah ungkapan untuk menyatakan rasa hormat, puji syukur, dan pujian serta sukacita kepada Tuhan karena telah mengasihi dan yang menyelamatkan sehingga melalui ibadah itu orang percaya bisa berjumpa dengan Allah dan melakukan apa yang menjadi kehendak-Nya.

Ibadah secara offline sekalipun mengandung kelebihan, tetapi juga mengandung berbagai kelemahan. Meskipun demikian ibadah secara offline Allah berkenan hadir untuk menyapa umatNya melalui instrumen ibadah ini. Demikian juga ibadah secara online sekalipun mengandung berbagai keunggulan, tetapi tidak luput dari berbagai kelemahan yang ada. Karena itu menuntut kedewasaan iman dari setiap orang percaya ketika mengikuti ibadah ini. Sama seperti ibadah secara offline, demikian juga ibadah secara online juga bisa dipakai oleh Allah untuk hadir menyapa umatNya melalui berita firmanNya.

Ibadah online apabila dikaitkan dengan masa dan paska pandemi covid-19 masih tetap relevan untuk tetap diselenggarakan. Ibadah secara online masih tetap relevan untuk menjawab pribadi-pribadi tertentu oleh 
karena kedaulatannya sehingga tidak bisa mengikuti ibadah secara offline. Jadi ibadah offline dan online bisa diselenggarakan secara paralel untuk menjangkau semua orang percaya untuk mengikuti ibadah dengan segala kondisi yang ada. Di era teknologi digital yang sedemikian maju dan berkembang dengan pesat gereja harus menggunakan berbagai media untuk menjalankan tugas dan panggilannya supaya Injil Kristus bisa diberitakan diberbagai tempat dengan menembus berbagai kesulitan.

\section{DAFTAR PUSTAKA}

Adani, Mohammad Robith. "Pengertian Internet, Sejarah, Perkembangan, Dan Manfaatnya." Sekawan Media, 2020. https://www.sekawanmedia.co.id/pengertian-internet.

B.K. Kuiper. The Church in History. Malang: Gandum Mas, 2010.

Dever, Mark. Tanda Gereja Yang Sehat. Surabaya: Momentum, 2010.

Ensiklopedi Alkitab Masa Kini, Jilid I. Jakarta: Yayasan Komunikasi Bina Kasih, 1997.

Guthrie, Donald. Tafsiran Alkitab Abad Ke-21, Jilid 3 Matius - Wabyu. jakarta: Yayasan komunikasi Bina Kasih, 2017.

Labberton, Mark. Bahaya Ibadah Sejati. Surabaya: Lieratur Perkantas Jawa Timur, 2011.

Langfan, Onisimus. "Ibadah Online Di Masa Pandemi Covid-19: Implementasi Ibrani 12:28." Stella: Jurnal Teologi Dan Pendidikan Kristen 1, no. 1 (2021): 15-18. http://sttse.ac.id/ejournal/index.php/stella.

Lennox, John C. Where Is God in A Coronavirus World? Surabaya: Literatur Perkantas Jatim, 2020.

"Memahami Epidemiologi Dan Istilah-Istilahnya," n.d. https://www.alodokter.com/memahami-epidemiologi-dan-istilahistilahnya.

Paterson, David. Liturgika: Sebuah Teologi Penyembahan. Malang: Gandum Mas, 2017.

"Pengertian Online Dan Offline Secara Lebih Jelas (," n.d. http://www.pengertianku.net/2015/01/pengertian-online-danoffline-secara-lebih-jelas.html). 
Piper, John. Coronavirus and Christ (Kristus Dan Virus Corona). Surabaya: Literatur Perkantas, 2020.

www.com. "Pola Penyebaran Virus Corona Dan Berita Populer Kesehatan Lainnya," 2020. https://www.suara.com.

Pranita, Ellyvon. "Diumumkan Awal Maret, Ahli: Virus Corona Masuk Indonesia Dari Januari." Kompas.Com, 2020. https://www.kompas.com/sains/read/2020/05/11/130600623/diu mumkan-awal-maret-ahli--virus-corona-masuk-indonesia-darijanuari.

Rachman, Rasid. Pembimbing Ke Dalam Sejarah Liturgi. jakarta: BPK Gunung Mulia, 2010.

Sedarmayanti, and Syarifudin Hidayat. Metode Penelitian. Bandung: Mandar Maju, 2011.

Tambunan, Fernando. "Analisis Dasar Teologi Terhadap Pelaksanaan Ibadah Online Pascapandemi Covid-19." EPIGRAPHE: Jurnal Teologi Dan Pelayanan Kristiani 4, no. 2 (November 28, 2020): 154. https://doi.org/10.33991/epigraphe.v4i2.210.

Whife, James F. Pengantar Ibadah Kristen. Jakarta: BPK Gunung Mulia, 2017.

SUNARTO, adalah dosen teologi di ST'T SAPPI Ciranjang. Beliau menyelesaikan program Sarjana Teologi di STT Injili Abdi Allah dan Magister Teologi di STT Baptis Indonesia, Semarang. 